\title{
Paideusis
}

\section{Children, Philosophy and Democracy (John P. Portelli and Ronald F. Reed (Eds.))}

\section{Michael Schleiffer}

Volume 9, Number 1, 1995

URI: https://id.erudit.org/iderudit/1073250ar

DOI: https://doi.org/10.7202/1073250ar

See table of contents

Publisher(s)

Canadian Philosophy of Education Society

ISSN

0838-4517 (print)

1916-0348 (digital)

Explore this journal

Cite this review

Schleiffer, M. (1995). Review of [Children, Philosophy and Democracy (John P. Portelli and Ronald F. Reed (Eds.))]. Paideusis, 9(1), 23-23.

https://doi.org/10.7202/1073250ar

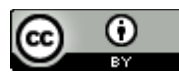

This document is protected by copyright law. Use of the services of Erudit (including reproduction) is subject to its terms and conditions, which can be viewed online.

https://apropos.erudit.org/en/users/policy-on-use/
This article is disseminated and preserved by Érudit.

Érudit is a non-profit inter-university consortium of the Université de Montréal, Université Laval, and the Université du Québec à Montréal. Its mission is to promote and disseminate research.

https://www.erudit.org/en/ 


\section{Book Reviews}

John P. Portelli and Ronald F. Reed (Eds.), Children, Philosophy and Democracy. Calgary: Detselig Enterprises, 1995.

This collection of essays is divided into three sections of which my' personal favourite was the third entitled "Pedagogical Possibilities in Philosophy for/with Children." This group was written primarily by practitioners who have been experimenting with the philosophy-for-children approach at different levels. Glynis Ross (ch. 12) and Reenie Marx (ch. 13) demonstrate how the teaching of literature at the high-school level (and higher) can incorporate the spirit of this approach, all the while extending the materials beyond the official texts from the Montclair Institute. Sharon Palermo (ch. 14) does a similar job for primary-school level. Furthermore, different formats can be experimented with (debates, juries, and small group discussions) without violating the spirit of encouraging dialogue and proper thinking. Too many followers of Philosophy for Children worry about the "orthodox" approach, which leads paradoxically to the kind of dogmatism never intended by Matthew Lipman and Ann Margaret Sharp.

This theme of the openness and flexibility of the Philosophy for Children "movement" is also expressed by John Portelli in his "Dialog [sic] of Hope" (ch. 5) with Susan Church. Useful points are made by Portelli about prejudices widely held about philosophy as well as the distinction he and Reed make between the Lipman-Sharp approach and the more general movement of teaching philosophy to children. These points, as well as others, will be of interest to readers despite the parochial nature of the debate about "whole language" which reflects more the local concerns in Nova Scotia than an issue of wider interest.

The essay by Portelli and Church (ch. 5) is part of a section entitled "Character of Philosophy for Children." In this section, the essay by Pritchard (ch. 1) entitled "Reasonable Children" raises the question of the relationship between philosophy and moral education. The key point, which, although not new, is worth repeating, stresses the importance of concepts in moral education. Another essay with which I found myself nodding in agreement is by Matthews entitled "Thoughts after Piaget." Once again, this point has been made before but it is worth emphasizing: no strong arguments based on an "orthodox" interpretation of Piaget's research in developmental psychology can be found to demonstrate that doing philosophy with very young children is inappropriate.

The chapters mentioned above by Portelli, Church, and Reed have been printed elsewhere. It should be noted that the two chapters by Lipman (on education and violence) and Sharp (on feminism) are also reprints. For those who may have missed them, their appearance in this collection would alone justify the purchase of the book.

Reviewed by Michael Schleiffer, Université de Québec à Montreal 